\title{
Removal of Hexavalent Chromium from Aqueous Solution by Adsorption on Palm Oil Fuel Ash (POFA)
}

\author{
Nurulhana Nordin', Nur Amirah Ahmad Asmadi1, Mohan Kumar Manikam1, \\ Azhar Abdul Halim ${ }^{1}$, Marlia Mohd Hanafiah ${ }^{1,2}$, Sarah Nadira Hurairah1 \\ ${ }^{1}$ Center for Earth Sciences and Environment, Faculty of Science and Technology, Universiti Kebangsaan Malaysia, Bangi, \\ Selangor, Malaysia \\ ${ }^{2}$ Centre for Tropical Climate Change System, Institute of Climate Change, Universiti Kebangsaan Malaysia, Bangi, Selangor, \\ Malaysia \\ Email: *azharhalim@ukm.edu.my
}

How to cite this paper: Nordin, N., Asmadi, N. A. A., Manikam, M. K., Halim, A. A., Hanafiah, M. M., \& Hurairah, S. N. (2020). Removal of Hexavalent Chromium from Aqueous Solution by Adsorption on Palm Oil Fuel Ash (POFA). Journal of Geoscience and Environment Protection, 8, 112-127. https://doi.org/10.4236/gep.2020.82008

Received: December 12, 2019

Accepted: February 17, 2020

Published: February 20, 2020

Copyright $\odot 2020$ by author(s) and Scientific Research Publishing Inc. This work is licensed under the Creative Commons Attribution International License (CC BY 4.0).

http://creativecommons.org/licenses/by/4.0/

(c) (i) Open Access

\begin{abstract}
This study investigated the removal of hexavalent chromium, $\mathrm{Cr}(\mathrm{VI})$ from aqueous solution by adsorption using palm oil fuel ash (POFA), an agricultural waste from the palm oil industry. POFA adsorbent was characterized by $\mathrm{X}$-ray diffraction (XRD) analysis. Batch adsorption study revealed that the optimum conditions for the removal were as follows: $\mathrm{pH} 2$, adsorbent dosage $80 \mathrm{~g} / \mathrm{L}$ and contact time of $6 \mathrm{~min}$, which resulted in $92 \%$ removal and 0.464 $\mathrm{mg} / \mathrm{g}$ maximum adsorption capacity. Adsorption isotherm and kinetic studies showed that Freundlich isotherm and pseudo-second-order kinetic models fitted best to the experimental data. Column adsorption study at $5 \mathrm{~mL} / \mathrm{min}$ of flow rate showed that $90 \%$ removal was obtained at $2 \mathrm{~min}$ of contact time which represented its breakthrough point. The column reached saturation at $30 \mathrm{~min}$ and the maximum column adsorption capacity recorded was 0.412 $\mathrm{mg} / \mathrm{g}$. The column adsorption behavior showed good fit with both Thomas and Yoon-Nelson kinetic models. These findings suggested that the utilization of POFA as a low-cost adsorbent to remove $\mathrm{Cr}(\mathrm{VI})$ from wastewater, either in batch or fixed bed adsorption system is not only effective, but concurrently will help to reduce wastes from the palm oil industry.
\end{abstract}

\section{Keywords}

Hexavalent Chromium, Palm Oil Fuel Ash (POFA), Low Cost Adsorbent, Adsorption Isotherms, Adsorption Kinetics

\section{Introduction}

Chromium in the form of hexavalent is a pollutant that has a significant impact 
on the environment and health due to its toxic, carcinogenic and mutagenic properties. Anthropogenic activities such as skin processing, electroplating, pigment industry and metal mining-based industry had the potential to be a source of chromium contamination in soil and natural water sources (Bibi et al., 2016; Choppala et al., 2013). Generally, chromium exists in the environment as hexavalent, $\mathrm{Cr}(\mathrm{VI})$ and trivalent, $\mathrm{Cr}(\mathrm{III})$ species. Trivalent chromium is less toxic compared to hexavalent chromium, and it also functioned as a major micronutrient for glucose metabolism in the human body (Gheju et al., 2016; Shahid et al., 2017). However, trivalent chromium can be oxidized into hexavalent chromium, causing serious environmental concern and danger to human health. Lung cancer, dermatitis, kidney and liver failure are examples of human toxicity upon inhalation, ingestion or dermal absorption of the hexavalent chromium exposure from soils and water bodies or wastewater.

There are many chemical and physical treatment processes which have been carried out to remove hexavalent chromium, $\mathrm{Cr}(\mathrm{VI})$ from wastewater, including chemical precipitation, ion exchange, coagulation, reverse osmosis, electrolysis, chemical reduction, and adsorption (Halim \& Ahmad, 2013). Due to its effectiveness and simple operation, adsorption method becomes the most preferable treatment for heavy metals removal from wastewater. However, conventional use of commercially available adsorbent like activated carbon involving high cost for industrial application. Thus, raising need for many recent studies to develop a low-cost adsorbent from readily available materials such as agricultural wastes. Agricultural wastes which are abundant in source are mainly consisting of cellulosic structure, which makes them an effective adsorbent for heavy metal ions (Guiza, 2017). Several recent studies involving agricultural wastes as adsorbent for $\mathrm{Cr}(\mathrm{VI})$ removal included usage of bamboo (Dula et al., 2014), rice straw (Kumar et al., 2017), coffee husk (Berihun, 2017), tea wastes, coconut shell and orange peel (Amir et al., 2017). In this study, palm oil wastes in the form of ash were used for $\mathrm{Cr}(\mathrm{VI})$ removal.

Palm oil fuel ash (POFA) is the by-product from burning process of oil palm shells, fibres and empty fruit bunches, which used as a fuel in the boiler to produce steam for electricity generation of milling processes. In Malaysia, it has been reported that more than 4 million tonnes of POFA were generated annually, and these numbers are expected to be increased due to increasing global demand for palm oil (Abdul Khalil et al., 2011). In common practice, POFA was simply disposed in landfill due to its limited usage and difficulties to be managed. Consequently, this huge amount of wastes has raised the environmental concerns in terms of increasing potential source of toxic pollutants in the landfill and its possible danger to human health. Therefore, as an approach to reduce the wastes from palm oil mill, there is little number of previous studies that have utilized POFA which is high in carbon and silica content (Utama et al., 2018) as the adsorbent material for treating wastewater (Manikam et al., 2019). To date, there is very limited research has been conducted involving usage of POFA for heavy metals removal from wastewater. Recent study by Imla Syafiqah \& Yussof, 2018 
has revealed that POFA was an effective and suitable adsorbent for mercury removal. However, fixed bed adsorption analysis was not conducted in the mentioned study. Thus, this present paper includes the column adsorption study to illustrate the design of continuous flow of adsorption.

The purpose of this study was to determine the effectiveness of POFA as a low-cost adsorbent for $\mathrm{Cr}(\mathrm{VI})$ removal from aqueous solution. Effects of $\mathrm{pH}$, adsorbent dosage and contact time to the adsorption performance were also studied through batch and column adsorption method. Adsorption isotherms and kinetics of this study were also explained based on the related models. Characterization of POFA using X-ray diffraction (XRD) instrument was also conducted to identify the crystalline phase of the adsorbent.

\section{Materials and Methods}

\subsection{Preparation of Palm Oil Fuel Ash (POFA) Adsorbent}

The POFA which collected from local palm oil estate was washed with distilled water and then dried at $105^{\circ} \mathrm{C}$ in oven for $24 \mathrm{~h}$. It was then ground to powder and sieved to obtain an average particle size of less than $250 \mu \mathrm{m}$.

\subsection{Characterization of POFA Adsorbent}

In order to perform characterization of POFA adsorbent, X-ray diffraction (XRD) test was conducted using XRD instrument (Brand: Bruker, Model: D8 Advance). $\mathrm{X}$-ray diffractogram of powdered POFA was obtained and later studied to identify the crystalline phase of the adsorbent.

\subsection{Preparation of Hexavalent Chromium [Cr(VI)] Aqueous Solution}

A total of $0.28 \mathrm{~g}$ potassium dichromate $\left(\mathrm{K}_{2} \mathrm{Cr}_{2} \mathrm{O}_{7}\right)$ powder (AR grade) was used to prepare a $100 \mathrm{mg} / \mathrm{L} \mathrm{Cr}(\mathrm{VI})$ stock solution in a $1000 \mathrm{~mL}$ volumetric flask, by dissolving the powder with de-ionized water. The concentration of $\mathrm{Cr}(\mathrm{VI})$ in the solution was determined based on the standard method by APHA (2005), using the test method by HACH (2014) - Method 1,5 Diphenylcarbohydrazide (Method 8023). The concentration measurement was taken using HACH DR 2700 spectrophotometer.

\subsection{Batch Adsorption Experiments}

Batch adsorption experiments of this study involved three main analyses which were determination of optimum parameters, adsorption isotherms and adsorption kinetics studies. The optimum parameters studied were $\mathrm{pH}$, adsorbent dosage and contact time. To study the $\mathrm{Cr}(\mathrm{VI})$ removal from aqueous solution by adsorption on POFA adsorbent, series of $250 \mathrm{~mL}$ conical flasks were filled with $100 \mathrm{~mL}$ of $\mathrm{Cr}$ (VI) solution. Different $\mathrm{pH}$ of $\mathrm{Cr}$ (VI) solution ( $\mathrm{pH}$ 2.0, 2.5, 3.5, 4.0, 4.5 and 5.0) were used to determine its optimum $\mathrm{pH}$, where the $\mathrm{pH}$ of the solution was adjusted by using sulfuric acid or sodium hydroxide. Then, to deter- 
mine the optimum adsorbent dosage, different mass of POFA adsorbent were used for making up to the adsorbent dosage of 5, 10, 20,40,60,80, 100 and 150 $\mathrm{g} / \mathrm{L}$. All the conical flasks were sealed with parafilm, placed on an orbital shaker and agitated at $200 \mathrm{rpm}$ shaking speed for predetermined contact time $(1,2,4,6$, 10, 15, 20 and $30 \mathrm{~min}$ ). These different contact times assigned to the adsorption process in order to determine its optimum contact time for the $\mathrm{Cr}(\mathrm{VI})$ removal. Upon the completion of adsorption process, the solution was filtered by $0.45 \mu \mathrm{m}$ nylon membrane filter, and the concentration of residual $\mathrm{Cr}(\mathrm{VI})$ in the solution was analyzed spectrophotometrically as mentioned in Section 2.3. The following batch adsorption experiment was conducted only at optimum parameters condition, in order to obtain the optimum $\mathrm{Cr}(\mathrm{VI})$ removal and maximum adsorption capacity of POFA adsorbent. For adsorption isotherms study, data from the determination of optimum adsorbent dosage experiment were used to plot the linear graph based on two adsorption isotherm models namely Langmuir and Freundlich. Meanwhile, adsorption kinetic of this study was identified using the data from determination of optimum contact time experiment. The data were used to plot the linear graph based on pseudo-first order and pseudo-second order adsorption kinetic models. Figure 1(a) shows the schematic diagram of batch adsorption experiment.

\subsection{Fixed Bed Column Adsorption Experiments}

Fixed bed column adsorption experiments were conducted using a column with $30 \mathrm{~cm}$ height and $2.5 \mathrm{~cm}$ diameter. A total of $36.4 \mathrm{~g}$ of powdered POFA adsorbent were placed in the column, layered with glass wool as supporting layers to form the adsorption media. By using peristaltic pump (Brand: Longer), $100 \mathrm{mg} / \mathrm{L}$ $\mathrm{Cr}(\mathrm{VI})$ aqueous solution was streamed in up-flow mode into the column and through the adsorption media at $5 \mathrm{~mL} / \mathrm{min}$ of flow rate. Effluent samples were collected at the predetermined contact time of 2, 10, 20,30, 40, and $50 \mathrm{~min}$. These samples were then analyzed using spectrophotometer to obtain the final concentration of $\mathrm{Cr}(\mathrm{VI})$ in the solution as mentioned in section 2.3. Thomas and Yoon-Nelson kinetic models were then used to investigate the mechanism of the column adsorption of $\mathrm{Cr}(\mathrm{VI})$ on POFA adsorbent. Figure $1(\mathrm{~b})$ shows the schematic diagram of fixed bed column adsorption experiment.

\subsection{Calculation of $\operatorname{Cr}(\mathrm{VI})$ Adsorption}

By using the spectrophotometer and method as mentioned in Section 2.3, the percentage of $\mathrm{Cr}(\mathrm{VI})$ removal, $R(\%)$ was calculated using the Equation (1):

$$
R(\%)=\frac{C_{i}-C_{f}}{C_{i}} \times 100
$$

where $C_{i}$ and $C_{f}$ are the initial and final concentration of $\mathrm{Cr}(\mathrm{VI})$ in aqueous solution before and after adsorption $(\mathrm{mg} / \mathrm{L})$ respectively.

Meanwhile, the amount of $\mathrm{Cr}(\mathrm{VI})$ adsorbed on POFA adsorbent at equilibrium, $q_{e}(\mathrm{mg} / \mathrm{g})$ was calculated using the Equation (2): 


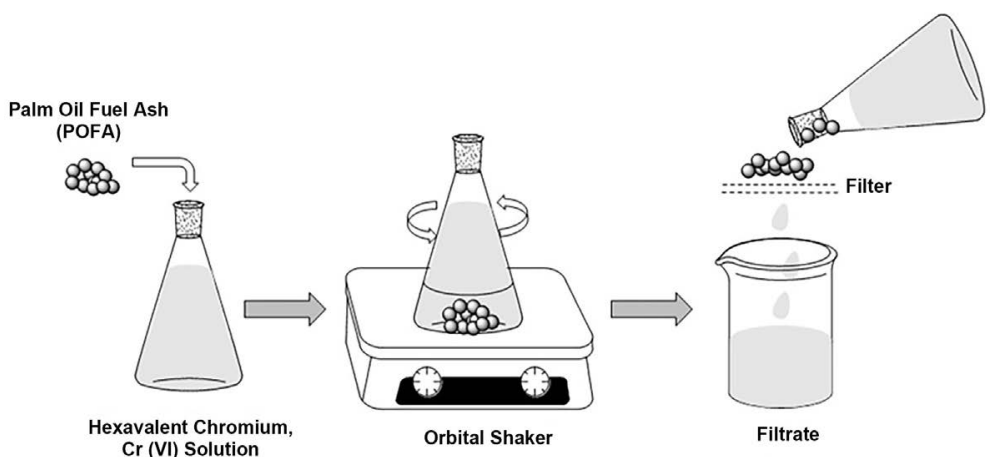

(a)

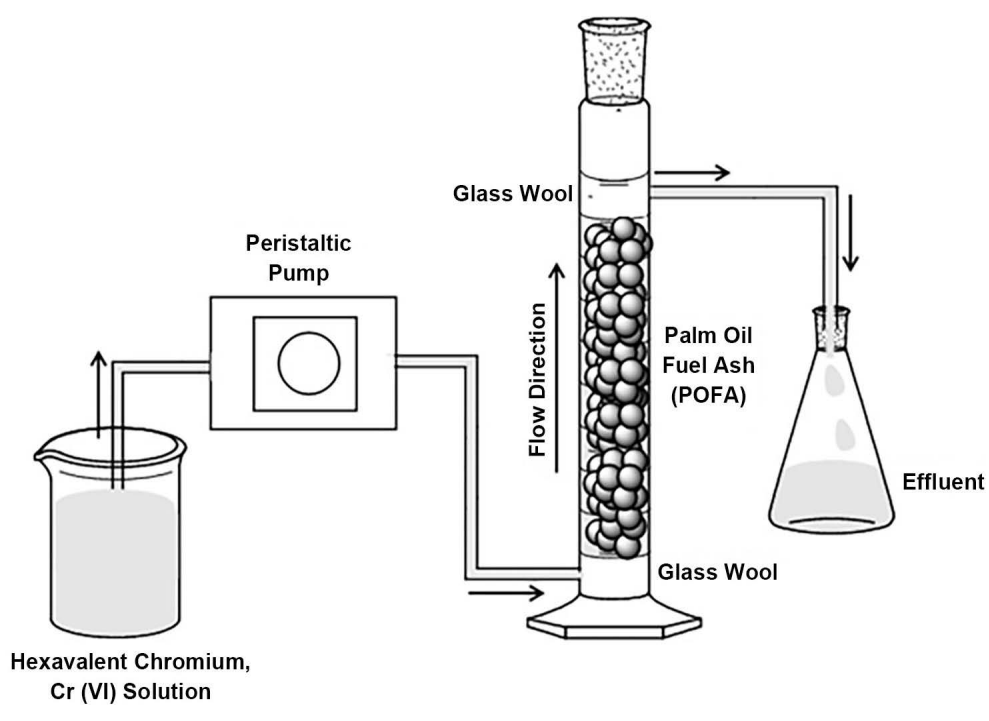

(b)

Figure 1. (a) Schematic diagram of batch adsorption experiment. (b) Schematic diagram of fixed bed adsorption experiment.

$$
q_{e}=\frac{\left(C_{0}-C_{e}\right) V}{W}
$$

where $C_{0}$ and $C_{e}$ are the initial and equilibrium concentration of $\mathrm{Cr}(\mathrm{VI})$ in aqueous solution $(\mathrm{mg} / \mathrm{L})$ respectively, $V$ is the volume of solution $(\mathrm{L})$ and $W$ is the mass of POFA adsorbent (g).

\section{Results and Discussion}

\subsection{Characterization of POFA Adsorbent}

Crystalline phase of POFA adsorbent was identified by XRD analysis over a scanning interval at 2 theta $(2 \theta)$ and angle ranging from $16^{\circ}$ to $52^{\circ}$. Figure 2 shows the XRD spectrum of POFA adsorbent. The peaks observed from the diffractogram indicate crystalline phase of POFA adsorbent, which determined as quartz (silica, $\mathrm{SiO}_{2}$ ) with $89.7 \mathrm{wt} \%$ and calcium silicate, $\mathrm{Ca}_{2} \mathrm{SiO}_{4}$ with $10.3 \mathrm{wt} \%$. Strong and sharp peak observed at $26^{\circ}$ represents good crystallinity of the adsorbent. 


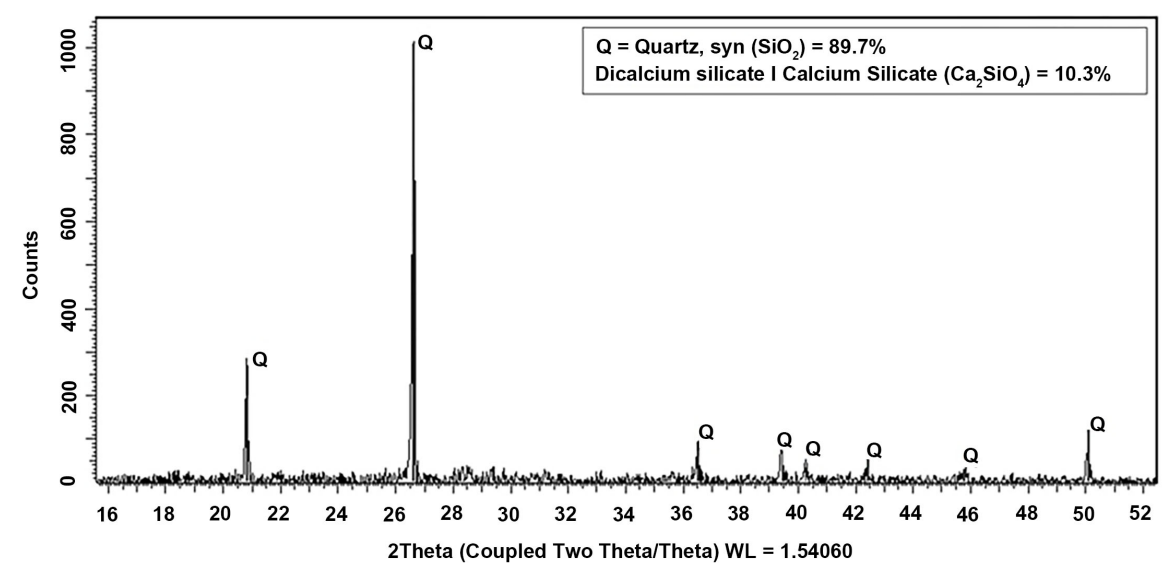

Figure 2. XRD spectrum of POFA adsorbent.

\subsection{Batch Adsorption Studies}

\subsubsection{Effect of $\mathrm{pH}$, Dosage and Contact Time}

Surface properties of the adsorbent and active form of metal ions are influenced by the $\mathrm{pH}$ of the solution, thus it is an important parameter for adsorption study. Experiment conducted at $\mathrm{pH}$ ranging from 2.0 to 5.0 showed that the optimum $\mathrm{pH}$ for $\mathrm{Cr}(\mathrm{VI})$ removal was $\mathrm{pH} 2.0$ of which $46 \%$ of removal were achieved. As the $\mathrm{pH}$ of the solution increased, the adsorption performance decreased, with a little fluctuation observed during $\mathrm{pH} 3.0$ to 5.0 (Figure 3(a)), which represented by low percentage of $\mathrm{Cr}(\mathrm{VI})$ removal. This trend indicates that the adsorption of $\mathrm{Cr}(\mathrm{VI})$ by POFA adsorbent was strongly dependent by $\mathrm{pH}$ and favourable in lower $\mathrm{pH}$. In acidic condition, the surface of POFA adsorbent was protonated and the dominant species of $\mathrm{Cr}(\mathrm{VI})$ in the solution was hydrogen chromate, $\mathrm{HCrO}_{4}^{-}$ ion. Hence, allowing strong electrostatic attraction between the positive charge of the adsorbent surface and negative charge of the metal ion. The concentration of $\mathrm{HCrO}_{4}^{-}$ion was high at lower $\mathrm{pH}$, resulted higher chromium adsorption capacity on the POFA adsorbent. While $\mathrm{pH}$ increased, this ion concentration decreased, lead to lower chromium uptake. Recent studies by Berihun (2017) and Rai et al. (2016) had reported similar trend for Cr(VI) removal using other adsorbents. The fluctuation observed which is similar to the previous study by Song et al. (2016) was due to unstable repulsive force between POFA adsorbent and chromium ions caused by abundance of $\mathrm{OH}^{-}$ions when the $\mathrm{pH}$ was slightly increased, resulted in little fluctuation of $\mathrm{Cr}(\mathrm{VI})$ removal.

Figure 3(b) shows the effect of the POFA adsorbent dosage ranging from 5 to $150 \mathrm{~g} / \mathrm{L}$ to the efficiency of $\mathrm{Cr}(\mathrm{VI})$ removal by adsorption. Initially, the percentage of $\mathrm{Cr}(\mathrm{VI})$ removal increased proportionally with adsorbent dosage, until it reached the equilibrium. Highest removal of $\mathrm{Cr}(\mathrm{VI})$ with $92 \%$ efficiency was achieved at the optimum adsorbent dosage of $80 \mathrm{~g} / \mathrm{L}$. The removal of $\mathrm{Cr}(\mathrm{VI})$ increased with the increasing adsorbent dosage due to more available binding sites from greater surface area of the adsorbent. After equilibrium was reached, further increased of adsorbent dosage did not affect the removal efficiency, as it might be attributed to shortage of $\mathrm{Cr}(\mathrm{VI})$ ion in the solution to occupy the 


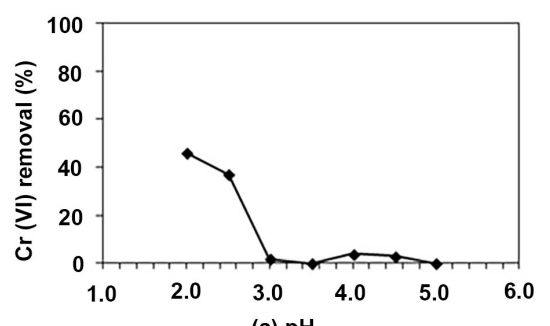

(a) $\mathrm{pH}$

(Initial concentration: $100 \mathrm{mg} /$, Adsorbent dosage: $1.0 \mathrm{~g} / 100 \mathrm{~mL}$ Agitation speed: $200 \mathrm{rpm}$, Contact time: $30 \mathrm{~min}$ )

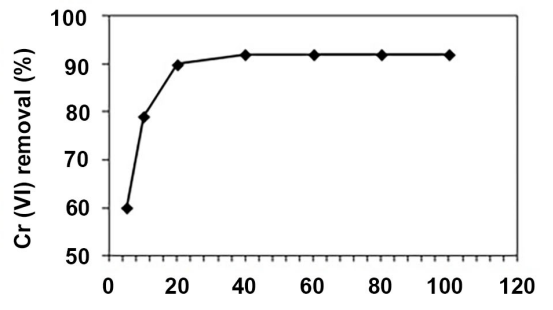

(b) POFA dosage (g/L)

(Initial concentration: $100 \mathrm{mg} / \mathrm{l}$ pH: 2 , Agitation speed: $200 \mathrm{rpm}$ Contact time: $30 \mathrm{~min}$ )

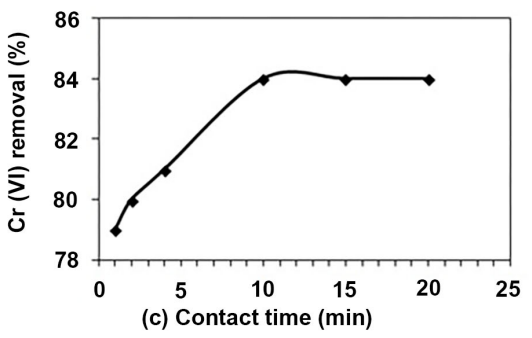

$$
\begin{gathered}
\text { (Initial concentration: } 100 \mathrm{mg} / \mathrm{l}, \\
\text { Adsorbent dosage: } 1.0 \mathrm{~g} / 100 \mathrm{~mL} \text {, } \\
\text { pH: } 2 \\
\text { Agitation speed: } 200 \mathrm{rpm} \text { ) }
\end{gathered}
$$

Figure 3. Effect of $\mathrm{pH}(\mathrm{a})$, adsorbent dosage (b) and contact time (c) to $\mathrm{Cr}(\mathrm{VI})$ removal by adsorption on POFA.

binding sites on the POFA adsorbent. Hence the adsorption remained constant. Previous studies by Owalude \& Tella (2016) and Dula et al. (2014) had reported similar behavior, where the $\mathrm{Cr}(\mathrm{VI})$ removal efficiency has increased with increasing dosage of adsorbent, which later has remained constant after equilibrium was achieved.

Effect of the contact time to $\mathrm{Cr}(\mathrm{VI})$ removal by adsorption on POFA adsorbent is illustrated in Figure 3(c). The removal percentage of $\mathrm{Cr}(\mathrm{VI})$ increased from 1 to 6 min where the maximum removal with $85 \%$ efficiency was observed at optimum contact time of $6 \mathrm{~min}$. During early stage of adsorption, greater number of available binding sites on POFA adsorbent allowed more chromium ions to be adsorbed resulted in higher percentage of $\mathrm{Cr}(\mathrm{VI})$ removal. As contact time increased, more binding sites were occupied and the surface of POFA adsorbent became exhausted, thus availability of more chromium ions to be adsorbed was reduced. Hence slightly decreasing of $\mathrm{Cr}(\mathrm{VI})$ removal efficiency was observed from 6 to $10 \mathrm{~min}$, before it finally remained constant onwards until 30 min of contact time. Several researchers included Panda et al. (2017) and Ali et al. (2016) had reported similar trend where the percentage of $\mathrm{Cr}(\mathrm{VI})$ removal has rapidly increased with contact time at initial stage, and later it attained the saturation level.

\subsubsection{Adsorption Isotherms}

Adsorption isotherm studies interpret the adsorption process behavior based on the interaction between the adsorbent and adsorbed molecules, while optimizing 
the adsorbent dosage used. The most appropriate adsorption isotherm models for this study, Langmuir and Freundlich were used to relate the equilibrium data obtained.

The Langmuir model's assumption is that maximum adsorption is associated with the formation of the saturated monolayer of the adsorbed molecules on the homogenous surface of the adsorbent (Langmuir, 1918). It suggests that no further adsorption occurred once the adsorption sites on the adsorbent were occupied by the adsorbed molecules. The linear equation of the Langmuir adsorption isotherms is given as Equation (3):

$$
\frac{1}{q_{e}}=\frac{1}{q_{m}}+\frac{1}{K_{L} q_{m} C_{e}}
$$

The value of Langmuir constant, $K_{L}(\mathrm{~L} / \mathrm{mg})$ and the maximum adsorption capacity, $q_{m}(\mathrm{mg} / \mathrm{g})$ were calculated by the slope and $\mathrm{y}$-intercept from the linear plot of $1 / q_{e}$ against $1 / C_{e}$, where $q_{e}(\mathrm{mg} / \mathrm{g})$ is the adsorption capacity at equilibrium and $C_{e}(\mathrm{mg} / \mathrm{L})$ is the concentration at equilibrium for each of the adsorbent dosage used.

Meanwhile, the Freundlich model assumes that multilayer adsorption takes place on heterogeneous surface of the adsorbent (Freundlich, 1906). The linear equation of Freundlich adsorption isotherm is given as Equation (4):

$$
\log q_{e}=\log K_{F}+\frac{1}{n} \log C_{e}
$$

The value of Freundlich constant, $K_{F}(\mathrm{mg} / \mathrm{g})$ and adsorption intensity, $n$ was determined by the y-intercept and the slope from the linear plot of $\log q_{e}$ against $\log C_{e}$, where both $q_{e}(\mathrm{mg} / \mathrm{g})$ is the amount adsorbed and $C_{e}(\mathrm{mg} / \mathrm{L})$ is the concentration at equilibrium.

The isotherm parameters data including constants and regression values, $R^{2}$ for both models is shown in Table 1. The result showed that the adsorption of $\mathrm{Cr}(\mathrm{VI})$ on POFA adsorbent fitted best with the Freundlich model due to its closer $R^{2}$ value to 1 . This concludes that the $\mathrm{Cr}(\mathrm{VI})$ removal in this study involved multilayer adsorption on heterogeneous surface of the POFA adsorbent. Recent studies by Yusuff (2018) using Leucaena leucocephala seed shell and Sugashini \& Begum (2015) using rice husk, have reported similar observations where the

Table 1. Adsorption isotherm data of $\mathrm{Cr}(\mathrm{VI})$ removal by adsorption on POFA.

\begin{tabular}{ccc}
\hline Adsorption Isotherm Model & Parameter & $\mathrm{Cr}(\mathrm{VI})$ \\
\hline \multirow{3}{*}{ Langmuir } & $R^{2}$ & 0.782 \\
& $q_{m}(\mathrm{mg} / \mathrm{g})$ & 0.464 \\
& $K_{L}(\mathrm{~L} / \mathrm{mg})$ & 0.035 \\
\hline \multirow{3}{*}{ Freundlich } & $R^{2}$ & 0.970 \\
& $n$ & 0.416 \\
& $K_{F}(\mathrm{mg} / \mathrm{g})$ & 0.001 \\
\hline
\end{tabular}


adsorption of $\mathrm{Cr}(\mathrm{VI})$ from aqueous solution has fitted closely to Freundlich adsorption isotherm model.

\subsubsection{Adsorption Kinetics}

Adsorption kinetics studies explain the adsorption mechanism of the absorbed material based on the results obtained at the time of equilibrium. In this study, the rate of $\mathrm{Cr}(\mathrm{VI})$ adsorption on POFA adsorbent was investigated using two adsorption kinetic models namely pseudo-first-order and pseudo-second-order. The linear equation of the pseudo-first-order adsorption kinetic is given as Equation (5) (Lagergren, 1898):

$$
\ln \left(q_{e}-q_{t}\right)=\ln q_{e}-K_{1} t
$$

The value of pseudo-first-order constant, $K_{1}\left(\mathrm{~min}^{-1}\right)$ and the adsorption capacity at equilibrium, $q_{e}$ (calculated) $(\mathrm{mg} / \mathrm{g})$ were determined from the slope and the y-intercept from the linear plot of $\ln \left(q_{e}-q_{t}\right)$ against contact time, $t$ (min), where $q_{e}$ (experimental) $(\mathrm{mg} / \mathrm{g})$ is the amount adsorbed at equilibrium and $q_{t}$ $(\mathrm{mg} / \mathrm{g})$ is the amount adsorbed at contact time.

Meanwhile, the linear equation of the pseudo-second-order adsorption kinetic is given as Equation (6) (Ho \& McKay, 1999):

$$
\frac{t}{q_{t}}=\frac{1}{K_{2} q_{e}^{2}}+\frac{1}{q_{e}}(t)
$$

The value of pseudo-second-order constant, $K_{2}\left(\mathrm{~g} \cdot \mathrm{mg}^{-1} \cdot \mathrm{min}^{-1}\right)$ and the adsorption capacity at equilibrium, $q_{e}$ (calculated) $(\mathrm{mg} / \mathrm{g})$ were determined from the $y$-intercept and the slope from the linear plot of $t / q_{t}$ against contact time, $t$ (min), where $q_{t}(\mathrm{mg} / \mathrm{g})$ is the amount adsorbed at contact time.

Table 2 shows the kinetic parameters data including constants, adsorption capacities and regression values, $R^{2}$ for both models. The results indicated that the experimental data represented best with pseudo-second-order kinetic model due to its $R^{2}$ value equals to 1 and its calculated adsorption capacity, $q_{e}$ was 8.446 $\mathrm{mg} / \mathrm{g}$ which agreed reasonably well to the experimental value of $8.417 \mathrm{mg} / \mathrm{g}$. These finding suggest that the adsorption of $\mathrm{Cr}(\mathrm{VI})$ on POFA adsorbent involved chemisorptions or ion exchange process. Previous studies by Ali et al. (2016) using banana peel and Ghasemi et al. (2015) using walnut shell have reported similar results where the $\mathrm{Cr}(\mathrm{VI})$ adsorption mechanism has described best by pseudo-second-order kinetic model.

\subsection{Column Adsorption Studies}

Figure 4 illustrates the breakthrough curve of $\mathrm{Cr}(\mathrm{VI})$ column adsorption by POFA adsorbent. The breakthrough point was observed at 2 min of contact time, where the effluent concentration recorded was $10 \%$ of the inlet concentration, indicating 90\% removal of $\mathrm{Cr}(\mathrm{VI})$. The steep curve from 2 until $20 \mathrm{~min}$ of contact time indicates rapid adsorption at initial stage. Then, from 20 to $30 \mathrm{~min}$ of contact time, the POFA adsorbent was started to be exhausted, resulted in less chromium ions uptake afterwards. After $30 \mathrm{~min}$ of contact time, the adsorbent 
Table 2. Adsorption kinetic data of Cr(VI) removal by adsorption on POFA.

\begin{tabular}{ccc}
\hline Adsorption Kinetic Model & Parameter & $\mathrm{Cr}(\mathrm{VI})$ \\
\hline & $q_{e}$ (experimental) $(\mathrm{mg} / \mathrm{g})$ & 8.417 \\
& $R^{2}$ & 0.717 \\
Pseudo-first-order & $q_{e}$ (calculated) $(\mathrm{mg} / \mathrm{g})$ & 0.509 \\
& $K_{1}\left(\mathrm{~min}^{-1}\right)$ & 0.074 \\
\hline \multirow{2}{*}{ Pseudo-second-order } & $R^{2}$ & 1.000 \\
& $q_{e}($ calculated $)(\mathrm{mg} / \mathrm{g})$ & 8.446 \\
& $K_{2}\left(\mathrm{~g} \cdot \mathrm{mg}^{-1} \cdot \mathrm{min}^{-1}\right)$ & 1.460 \\
\hline
\end{tabular}

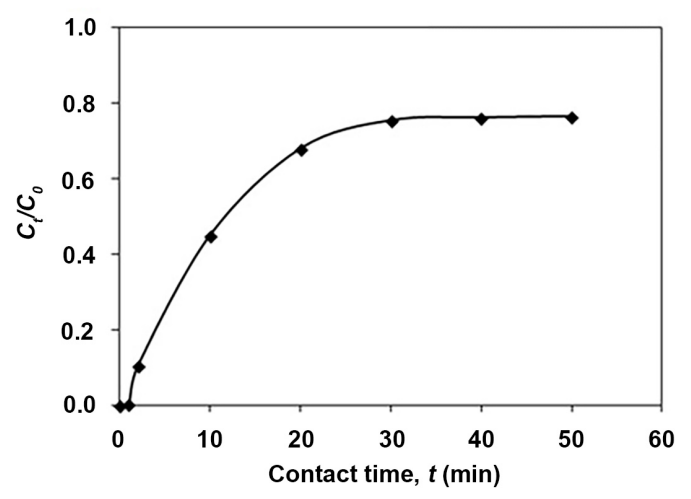

$\left(C_{0}\right.$ and $C_{t}$ : inlet and outlet $\mathrm{Cr}(\mathrm{VI})$ concentration respectively, flow rate: $5 \mathrm{~mL} / \mathrm{min}$, mass of POFA adsorbent packed in the columm: $36.4 \mathrm{~g}, \mathrm{pH}: 2$ )

Figure 4. Breakthrough curve for fixed bed column adsorption of $\mathrm{Cr}(\mathrm{VI})$ on POFA.

became exhausted and the saturation has been achieved, represented by the plateau of the breakthrough curve. The adsorption capacities at breakthrough point, $q_{b}(\mathrm{mg} / \mathrm{g})$ and at exhaustion time, $q_{e}(\mathrm{mg} / \mathrm{g})$ were calculated using the equation adapted from Taty-Costodes et al. (2005) given as Equation (7):

$$
q_{b}=\frac{Q t_{b} C_{0}}{m}
$$

where $Q(\mathrm{~L} / \mathrm{min})$ is the volumetric flow rate, $t_{b}(\mathrm{~min})$ is the breakthrough time, $C_{0}(\mathrm{mg} / \mathrm{L})$ is the inlet $\mathrm{Cr}(\mathrm{VI})$ concentration and $m(\mathrm{~g})$ is the amount of POFA adsorbent packed in the column. Table 3 shows adsorption breakthrough analysis data of this study. The experimental exhaustion adsorption capacity, $q_{e}$ for the column adsorption analysis, $0.412 \mathrm{mg} / \mathrm{g}$ was slightly lower than the maximum adsorption capacity, $q_{m}$ recorded from earlier batch adsorption analysis, which was $0.464 \mathrm{mg} / \mathrm{g}$. This is attributed to less effective surface area for the interaction between chromium ions and POFA adsorbent in fixed bed column system compared to the continuous stirred batch flasks.

In order to predict the dynamic behavior of the column adsorption of $\mathrm{Cr}(\mathrm{VI})$ on POFA adsorbent, the most common and widely used kinetic models, Thomas and Yoon-Nelson models were used to fit the experimental data. 
Table 3. Breakthrough analysis data of $\mathrm{Cr}(\mathrm{VI})$ column adsorption by POFA.

\begin{tabular}{lc}
\hline Adsorbent mass, $m(\mathrm{~g})$ & 36.4 \\
\hline Breakthrough time, $t_{b}(\mathrm{~min})$ & 2.0 \\
Breakthrough adsorption capacity, $q_{b}(\mathrm{mg} / \mathrm{g})$ & 0.028 \\
Exhaustion time, $t_{e}(\mathrm{~min})$ & 30.0 \\
Exhaustion adsorption capacity, $q_{e}(\mathrm{mg} / \mathrm{g})$ & 0.412 \\
\hline
\end{tabular}

Thomas model relates the adsorption process with Langmuir adsorption-desorption kinetics without axial dispersion. It suggests that the rate driving force of the adsorption follows second-order reversible reaction of kinetics (Thomas, 1944). The linear equation of the Thomas column adsorption kinetic model is given as Equation (8):

$$
\ln \left(\frac{C_{0}}{C_{t}}-1\right)=\frac{k_{T} q_{0(T)} m}{Q}-\frac{k_{T} C_{0}}{Q} V
$$

where $C_{0}(\mathrm{mg} / \mathrm{L})$ is the inlet $\operatorname{Cr}(\mathrm{VI})$ concentration in the solution, $C_{t}(\mathrm{mg} / \mathrm{L})$ is the outlet $\mathrm{Cr}(\mathrm{VI})$ concentration at time, $m(\mathrm{~g})$ is the amount of POFA adsorbent packed in the column, $Q(\mathrm{~L} / \mathrm{min})$ is the volumetric flow rate and $V(\mathrm{~L})$ is the volume of effluent. The value of Thomas constant, $k_{T}\left(\mathrm{~L} \cdot \mathrm{min}^{-1} \cdot \mathrm{mg}^{-1}\right)$ and maximum column adsorption capacity for this model, $q_{0(T)}(\mathrm{mg} / \mathrm{g})$ were calculated by the slope and y-intercept from the linear plot of $\ln \left[\left(C_{0} / C_{t}\right)-1\right]$ against $V$ (Figure 5)

Meanwhile, the Yoon-Nelson model assumes that the rate of decrease in the probability of adsorption of each adsorbate molecule is proportional to the probability of the adsorbate breakthrough on the adsorbent (Yoon \& Nelson, 1984). The linear equation of the Yoon-Nelson column adsorption kinetic model is given as Equation (9):

$$
\ln \left(\frac{C_{t}}{C_{0}-C_{t}}\right)=k_{Y N} t-\tau k_{Y N}
$$

where $C_{0}(\mathrm{mg} / \mathrm{L})$ is the inlet $\mathrm{Cr}(\mathrm{VI})$ concentration in the solution and $C_{t}(\mathrm{mg} / \mathrm{L})$ is the outlet $\mathrm{Cr}(\mathrm{VI})$ concentration at time, $t(\mathrm{~min})$. The value of Yoon-Nelson constant, $k_{Y N}\left(\mathrm{~min}^{-1}\right)$ and the time required for $50 \%$ adsorbate breakthrough, $\tau$ ( $\mathrm{min})$ were determined by the slope and $y$-intercept from the linear plot of $\ln \left[\left(C_{t} / C_{0}-C_{t}\right)\right]$ against $t$ (Figure 6). Then, the maximum column adsorption capacity for this model, $q_{0(Y M)}(\mathrm{mg} / \mathrm{g})$ was calculated using Equation (10):

$$
q_{\text {OYN }}=\frac{q_{\text {total }}}{m}=\frac{\frac{1}{2} C_{0}\left(\frac{Q}{100} \times 2 \tau\right)}{m}=\frac{C_{0} Q \tau}{1000 m}
$$

where $Q(\mathrm{~L} / \mathrm{min})$ is the volumetric flow rate and $m(\mathrm{~g})$ is the amount of POFA adsorbent packed in the column.

Table 4 shows the column adsorption kinetic parameters data including constants, adsorption capacities and regression values, $R^{2}$ for these models. It was observed that the experimental data fitted reasonably with both Thomas and Yoon-Nelson models due to similar $R^{2}$ values $>0.7$. The calculated values of 


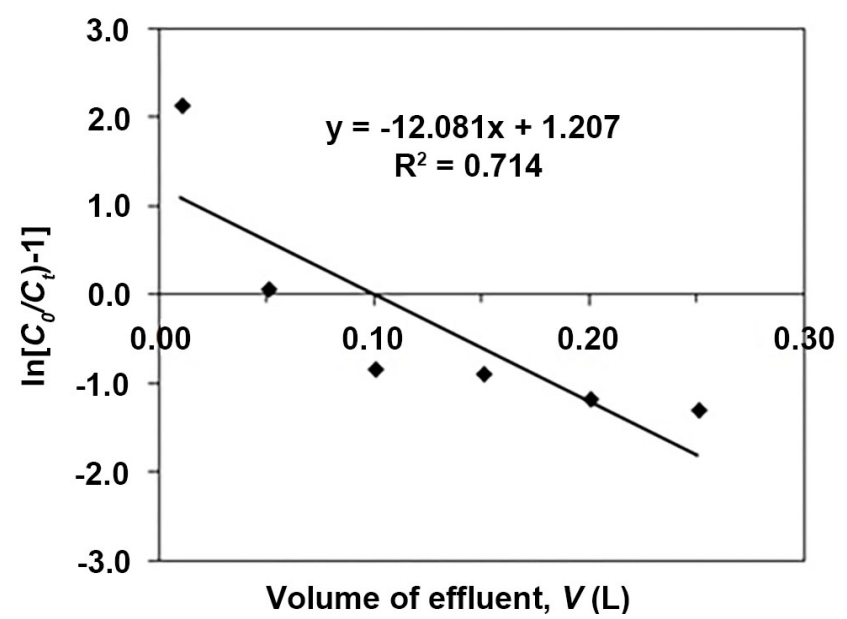

Figure 5. Thomas fixed bed adsorption kinetic model linear plots for $\mathrm{Cr}(\mathrm{VI})$ removal on POFA.

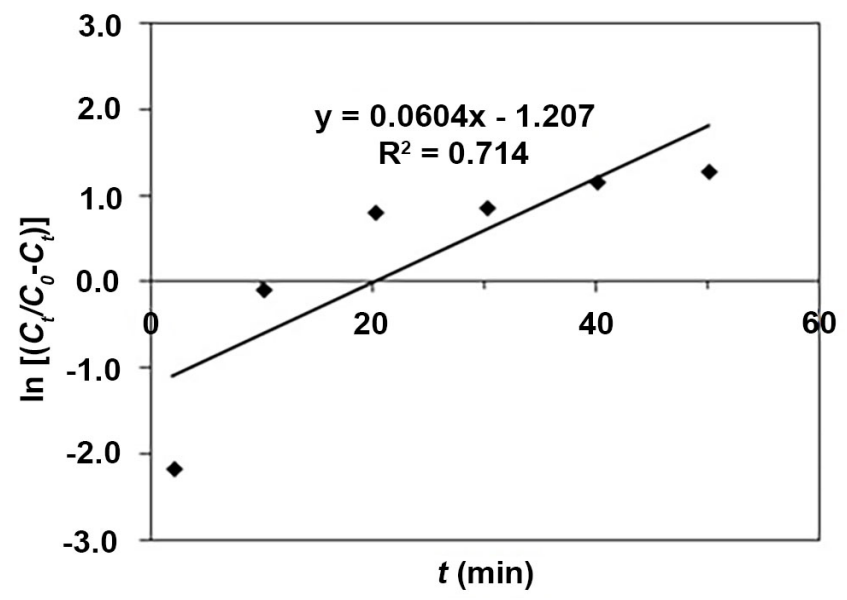

Figure 6. Yoon-Nelson fixed bed adsorption kinetic model linear plots for $\mathrm{Cr}(\mathrm{VI})$ removal on POFA.

Table 4. Column adsorption kinetic data of Cr(VI) removal by adsorption on POFA.

\begin{tabular}{ccc}
\hline Column Adsorption Kinetic Model & Parameter & $\mathrm{Cr}(\mathrm{VI})$ \\
\hline \multirow{2}{*}{ Thomas } & $q_{e}($ experimental $)(\mathrm{mg} / \mathrm{g})$ & 0.412 \\
& $R^{2}$ & 0.714 \\
& $k_{T}\left(\mathrm{~L} \cdot \mathrm{min}^{-1} \cdot \mathrm{mg}^{-1}\right)$ & 0.001 \\
& $q_{0(T)}(\mathrm{mg} / \mathrm{g})$ & 0.275 \\
\hline \multirow{2}{*}{ Yoon-Nelson } & $R^{2}$ & 0.714 \\
& $k_{Y N}\left(\mathrm{~min}^{-1}\right)$ & 0.060 \\
& $\tau(\mathrm{min})$ & 20.0 \\
& $q_{0(Y M)}(\mathrm{mg} / \mathrm{g})$ & 0.275
\end{tabular}

maximum adsorption capacities, $q_{0}$ were also similar for both models, which were $0.275 \mathrm{mg} / \mathrm{g}$ and it was comparable with the value of experimental exhaus- 
tion adsorption capacity, $q_{e}$ of $0.412 \mathrm{mg} / \mathrm{g}$.

Thus, it can be concluded that $\mathrm{Cr}(\mathrm{VI})$ removal by adsorption on POFA adsorbent in this study obeys Freundlich isotherm, pseudo-second-order, Thomas and Yoon-Nelson kinetic models. Recent study by Rodrigues et al. (2019) has reported similar findings of $\mathrm{Cr}(\mathrm{VI})$ adsorption on hydrotalcite adsorbent, where the adsorption behaviour has fitted well with the Freundlich isotherm and pseudo-second-order kinetic, which later confirmed by the agreement with Thomas model.

\section{Conclusion}

This study has shown that POFA is an effective low cost and readily available adsorbent for $\mathrm{Cr}(\mathrm{VI})$ removal from aqueous solution. From the batch adsorption study, the maximum removal of $\mathrm{Cr}(\mathrm{VI})$ has achieved at $92 \%$ efficiency with maximum adsorption capacity of $0.464 \mathrm{mg} / \mathrm{g}$. The adsorption performance of POFA adsorbent was strongly dependent on the parameters that have been studied. The optimum parameters observed for the $\mathrm{Cr}(\mathrm{VI})$ removal were $\mathrm{pH} 2$ of the solution, $80 \mathrm{~g} / \mathrm{L}$ of adsorbent dosage and $6 \mathrm{~min}$ of contact time. The adsorption isotherm was compliant with the Freundlich model which indicated that multilayer adsorption has occurred on heterogeneous surface of the adsorbent. The adsorption behavior also fitted best with pseudo-second-order kinetic model which suggested that the adsorption of $\mathrm{Cr}(\mathrm{VI})$ on POFA adsorbent has involved chemisorptions or ion exchange process. From the column adsorption study, maximum $90 \%$ of $\mathrm{Cr}(\mathrm{VI})$ removal has obtained at $2 \mathrm{~min}$ of contact time which represented its breakthrough point. The maximum column adsorption capacity was $0.412 \mathrm{mg} / \mathrm{g}$ and the column adsorption behavior has shown a good fit with both Thomas and Yoon-Nelson kinetic models.

In conclusion, utilization of POFA as adsorbent to remove $\mathrm{Cr}(\mathrm{VI})$ from wastewater not only will be cost effective, but concurrently will tackle the issue of huge wastes from palm oil industry by reducing the cost of the wastes management and disposal. This study also gives a market value for POFA which is originally a waste, to be sold commercially as a low-cost biodegradable adsorbent. These positive findings strongly suggest that the usage of POFA for further research involving water treatment analysis of other kinds of pollutants from various sources such as industrial wastewater will be potentially effective and economical.

\section{Acknowledgements}

The authors are thankful to the Center for Earth Sciences and Environment, Faculty of Science and Technology, Universiti Kebangsaan Malaysia for providing all necessary facilities required to carry out this study.

\section{Conflicts of Interest}

The authors declare no conflicts of interest regarding the publication of this paper. 


\section{References}

Abdul Khalil, H. P. S., Marliana, M. M., \& Alshammari, T. (2011). Material Properties of Epoxy-Reinforced Biocomposites with Lignin from Empty Fruit Bunch as Curing Agent. BioResources, 6, 5206-5223.

https://ojs.cnr.ncsu.edu/index.php/BioRes/article/view/BioRes_06_4_5206_AbdulKhali 1_MA_Prop_Epoxy_Biocomposites_Lignin

Ali, A., Saeed, K., \& Mabood, F. (2016). Removal of Chromium (VI) from Aqueous Medium Using Chemically Modified Banana Peels as Efficient Low-Cost Adsorbent. Alexandria Engineering Journal, 55, 2933-2942. https://doi.org/10.1016/j.aej.2016.05.011

Amir, A., Raja Abd Rahim, R. N., \& Abdul-Talib, S. (2017). Removal of Chromium Hexavalent Using Agriculture Waste. International Journal of Environmental Science and Development, 8, 260-263. https://doi.org/10.18178/ijesd.2017.8.4.959

APHA (2005). Standard Methods for the Examination of Water and Wastewater (21st ed.). Washington DC: American Public Health Association.

Berihun, D. (2017). Removal of Chromium from Industrial Wastewater by Adsorption Using Coffee Husk. Journal of Material Sciences and Engineering, 6, Article ID: 1000331. https://doi.org/10.4172/2169-0022.1000331

Bibi, I., Icenhower, J., Niazi, N. K., Naz, T., Shahid, M., \& Bashir, S. (2016). Chapter 21-Clay Minerals: Structure, Chemistry, and Significance in Contaminated Environments and Geological $\mathrm{CO}_{2}$ Sequestration. In M. N. V. Prasad, \& K. Shih (Eds.), Environmental Materials and Waste: Resource Recovery and Pollution Prevention (pp. 543-567). New York: Elsevier Inc. https://doi.org/10.1016/B978-0-12-803837-6.00021-4

Choppala, G., Bolan, N., \& Park, J. H. (2013). Chapter Two-Chromium Contamination and Its Risk Management in Complex Environmental Settings. Advances in Agrono my, 120, 129-172. https://doi.org/10.1016/B978-0-12-407686-0.00002-6

Dula, T., Siraj, K., \& Kitte, S. A. (2014). Adsorption of Hexavalent Chromium from Aqueous Solution Using Chemically Activated Carbon Prepared from Locally Available Waste of Bamboo (Oxytenanthera abyssinica). ISRN Environmental Chemistry, 2014, Article ID: 438245. https://doi.org/10.1155/2014/438245

Freundlich, H. M. (1906). Over the Adsorption in Solution. The Journal of Physical Chemistry, 57, 385-470.

Ghasemi, M., Ghoreyshi, A. A., Younesi, H., \& Khoshhal, S. (2015). Synthesis of a High Characteristics Activated Carbon from Walnut Shell for the Removal of $\mathrm{Cr}(\mathrm{VI})$ and $\mathrm{Fe}$ (II) from Aqueous Solution: Single and Binary Solutes Adsorption. Iranian Journal of Chemical Engineering, 12, 28-51.

Gheju, M., Balcu, I., \& Vancea, C. (2016). An Investigation of Cr(VI) Removal with Metallic Iron in the Co-Presence of Sand and/or $\mathrm{MnO}_{2}$. Journal of Environmental Management, 170, 145-151. https://doi.org/10.1016/j.jenvman.2016.01.013

Guiza, S. (2017). Biosorption of Heavy Metal from Aqueous Solution Using Cellulosic Waste Orange Peel. Ecological Engineering, 99, 134-140.

https://doi.org/10.1016/j.ecoleng.2016.11.043

HACH (2014). Chromium, Hexavalent 1,5-Diphenylcarbohydrazide Method-Method 8023 (9th ed.). Loveland, CO: Hach Company.

Halim, A. A., \& Ahmad, M. F. (2013). Isoterma dan Kinetik Penjerapan Boron oleh Batu Kapur Sebagai Penjerap Berkos Rendah [Isotherm and Kinetic Adsorption of Boron onto Limestone as a Low-Cost Adsorbent]. Sains Malaysiana, 42, 1689-1696.

Ho, Y. S., \& McKay, G. (1999). Pseudo-Second Order Model for Sorption Processes. 
Process Biochemistry, 34, 451-465. https://doi.org/10.1016/S0032-9592(98)00112-5

Imla Syafiqah, M. S., \& Yussof, H. W. (2018). Adsorption of Mercury from Aqueous Solutions using Palm Oil Fuel Ash as an Adsorbent-Batch Studies. IOP Conference Series: Materials Science and Engineering, 334, Article ID: 012039. https://doi.org/10.1088/1757-899X/334/1/012039

Kumar, R., Kumar Arya, D., Singh, N., \& Kumar Vats, H. (2017). Removal of Cr(VI) using Low Cost Activated Carbon Developed by Agricultural Waste. IOSR Journal of Applied Chemistry, 10, 76-79. https://doi.org/10.9790/5736-1001017679

Lagergren, S. (1898). About the Theory of So-Called Adsorption of Soluble Substance. Kungliga Svenska Vetenskapsakademiens Handlingar, 24, 1-39.

Langmuir, I. (1918). The Adsorption of Gases on Plane Surfaces of Glass, Mica and Platinum. Journal of the American Chemical Society, 40, 1361-1403. https://doi.org/10.1021/ja02242a004

Manikam, M. K., Halim, A. A., Hanafiah, M. M., \& Krishnamoorthy, R. R. (2019). Removal of Ammonia Nitrogen, Nitrate, Phosphorus and COD from Sewage Wastewater using Palm Oil Boiler Ash Composite Adsorbent. Desalination and Water Treatment, 149, 23-30. https://doi.org/10.5004/dwt.2019.23842

Owalude, S. O., \& Tella, A. C. (2016). Removal of Hexavalent Chromium from Aqueous Solutions by Adsorption on Modified Groundnut Hull. Beni-Suef University Journal of Basic and Applied Sciences, 5, 377-378. https://doi.org/10.1016/j.bjbas.2016.11.005

Panda, H., Tiadi, N., Mohanty, M., \& Mohanty, C. R. (2017). Studies on Adsorption Behavior of an Industrial Waste for Removal of Chromium from Aqueous Solution. South African Journal of Chemical Engineering, 23, 132-138. https://doi.org/10.1016/j.sajce.2017.05.002

Rai, M. K., Shahi, G., Meena, V., Meena, R., Chakraborty, S., Singh, R. S., \& Rai, B. N. (2016). Removal of Hexavalent Chromium Cr(VI) Using Activated Carbon Prepared from Mango Kernel Activated with H3PO4. Resource-Efficient Technologies, 2, S63-S70. https://doi.org/10.1016/j.reffit.2016.11.011

Rodrigues, E., Almeida, O., Brasil, H., Moraes, D., \& dos Reis, M. A. L. (2019). Adsorption of Chromium (VI) on Hydrotalcite-Hydroxyapatite Material Doped with Carbon Nanotubes: Equilibrium, Kinetic and Thermodynamic Study. Applied Clay Science, 172, 57-64. https://doi.org/10.1016/j.clay.2019.02.018

Shahid, M., Shamshad, S., Rafiq, M., Khalid, S., Bibi, I., Niazi, N. K., Dumat, C., \& Rashid, M. I. (2017). Chromium Speciation, Bioavailability, Uptake, Toxicity and Detoxification in Soil-Plant System: A Review. Chemosphere, 178, 513-533. https://doi.org/10.1016/j.chemosphere.2017.03.074

Song, D., Pan, K., Tariq, A., Azizullah, A., Sun, F., Li, Z., \& Xiong, Q. (2016). Adsorptive Removal of Toxic Chromium from Waste-Water Using Wheat Straw and Eupatorium adenophorum. PLOS ONE, 11, e0167037. https://doi.org/10.1371/journal.pone.0167037

Sugashini, S., \& Begum, K. (2015). Preparation of Activated Carbon from Carbonized Rice Husk by Ozone Activation for Cr(VI) Removal. New Carbon Materials, 30, 252-261. https://doi.org/10.1016/S1872-5805(15)60190-1

Taty-Costodes, V. C., Fauduet, H., Porte, C., \& Ho, Y. S. (2005). Removal of Lead (II) Ions from Synthetic and Real Effluents Using Immobilized Pinus sylvestris Sawdust: Adsorption on a Fixed-Bed Column. Journal of Hazardous Materials, 123, 135-144. https://doi.org/10.1016/j.jhazmat.2005.03.032

Thomas, H. C. (1944). Heterogeneous Ion Exchange in a Flowing System. Journal of the American Chemical Society, 66, 1664-1666. https://doi.org/10.1021/ja01238a017 
Utama, P. S., Saputra, E., \& Khairat. (2018). Effective Utilizations of Palm Oil Mill Fly Ash for Synthetic Amorphous Silica and Carbon Zeolite Composite Synthesis. IOP Conference Series: Materials Science and Engineering, 345, Article ID: 012009. https://doi.org/10.1088/1757-899X/345/1/012009

Yoon, Y. H., \& Nelson, J. H. (1984). Application of Gas Adsorption Kinetics I. A Theoretical Model for Respirator Cartridge Service Life. American Industrial Hygiene Association Journal, 45, 509-516. https://doi.org/10.1080/15298668491400197

Yusuff, A. S. (2018). Optimization of Adsorption of Cr(VI) from Aqueous Solution by Leucaena leucocephala Seed Shell Activated Carbon Using Design of Experiment. Applied Water Science, 8, 232. https://doi.org/10.1007/s13201-018-0850-3 